\title{
Efek Residu Kacang Hijau Pertanaman Pertama pada Pertumbuhan dan Hasil Kacang Tunggak Pertanaman Kedua di Lahan Kering
}

\section{(Residual Effect of Mungbean First Planting on Growth and Yield of Cowpea Second Planting in Dry Land)}

\author{
Sri Ayu Dwi Lestari*, Sutrisno, Andy Wijanarko, Henny Kuntyastuti \\ (Diterima Oktober 2019/Disetujui Agustus 2020)
}

\begin{abstract}
ABSTRAK
Penelitian ini bertujuan untuk mengetahui pengaruh residu pupuk dan bekas jarak tanam kacang hijau pertanaman pertama pada pertumbuhan dan hasil kacang tunggak pertanaman kedua di lahan kering. Penelitian dilaksanakan di IP2TP Muneng, Probolinggo, Jawa Timur pada musim kemarau (MK) tahun 2015. Benih kacang tunggak varietas KT 5 ditanam pada petak berukuran $4 \mathrm{~m} \times 4,5 \mathrm{~m}$ dengan jarak tanam $40 \mathrm{~cm} \times 15 \mathrm{~cm}, 2$ tanaman/lubang. Penelitian dilakukan tanpa penambahan pupuk (pupuk perlakuan hanya diberikan pada tanaman kacang hijau pertanaman pertama). Percobaan disusun dalam rancangan petak terpisah dengan tiga ulangan. Petak utama adalah bekas jarak tanam kacang hijau, yaitu 1) bekas jarak tanam $40 \mathrm{~cm} \times 10 \mathrm{~cm}$, satu tanaman/lubang (J1); 2) bekas jarak tanam $40 \mathrm{~cm} \times 15 \mathrm{~cm}$, dua tanaman/lubang (J2); dan 3) bekas jarak tanam $40 \mathrm{~cm} \times 20 \mathrm{~cm}$, dua tanaman/lubang (J3). Anak petak adalah residu kombinasi pupuk organik dan anorganik, yaitu 1) residu tanpa pupuk (R0); 2) residu pemupukan $50 \mathrm{~kg} \mathrm{ZA}+50 \mathrm{~kg} \mathrm{SP}-36+100 \mathrm{~kg} \mathrm{KCl} / \mathrm{ha}$ (R1); 3) residu pemupukan $150 \mathrm{~kg}$ Phonska/ha (R2); 4) residu pemupukan $5000 \mathrm{~kg}$ pupuk kandang/ha (R3); dan 5) residu pemupukan $75 \mathrm{~kg}$ Phonska $+2500 \mathrm{~kg}$ pupuk kandang/ha (R4). Hasil penelitian menunjukkan bahwa budi daya kacang tunggak dengan perlakuan R3 dan R4 memberikan pengaruh nyata pada bobot kering akar dan tajuk. Hasil biji tertinggi diperoleh pada perlakuan J3 dan R4 sebesar 1,62 t/ha dan biomas tertinggi diperoleh pada perlakuan J3 sebesar 5,92 t/ha, namun secara statistik tidak berbeda nyata dari perlakuan lainnya.
\end{abstract}

Kata kunci: kacang tunggak, lahan kering iklim kering, residu pupuk

\section{ABSTRACT}

The objective of this research was to determine the residual effect of fertilizer and former plant spacing of mungbean first planting on growth and yield of cowpea second planting in a dry land. The experiment was conducted at Muneng Research Field, Probolinggo, East Java during dry season in 2015. The cowpea seeds of KT 5 varieties were planted in plots measuring $4 \mathrm{~m} \mathrm{x} \mathrm{4,5} \mathrm{m} \mathrm{with} \mathrm{plant} \mathrm{spacing} \mathrm{of} 40 \mathrm{~cm} \times 15 \mathrm{~cm}, 2$ plants/hole. This research was carried out without adding fertilizer (fertilizer application only given on mungbean planting). This experiment was laid out in a split plot design and replicated three times. Plant spacing of mungbean as the main plot, namely 1) former of $40 \mathrm{~cm} \times 10 \mathrm{~cm}, 1$ plant/hole (J1); 2) former of $40 \mathrm{~cm} \mathrm{x} 15 \mathrm{~cm}, 2$ plants/hole (J2); and 3) former of $40 \mathrm{~cm} \times 20 \mathrm{~cm}, 2$ plants/hole (J3). Residual combination of organic and inorganic fertilizers as the sub plot, namely 1) former without fertilizer (R0); 2) former of $50 \mathrm{~kg} \mathrm{ZA}+50 \mathrm{~kg} \mathrm{SP}-36$ + $100 \mathrm{~kg} \mathrm{KCl} / \mathrm{ha}$ (R1); 3) former of $150 \mathrm{~kg}$ Phonska/ha (R2); 4) former of $5000 \mathrm{~kg}$ organic fertilizer/ha (R3); and 5) former of $75 \mathrm{~kg}$ Phonska $+2500 \mathrm{~kg}$ organic fertilizer/ha (R4). The results showed that the cultivation of cowpea with R3 and R4 treatments had effects on shoot and roots dry weights. The highest cowpea yield was obtained with $\mathrm{J} 3$ and $\mathrm{R} 4$ treatment of $1,62 \mathrm{t} / \mathrm{ha}$ and the highest biomass was obtained with J3 treatment of $5,92 \mathrm{t} / \mathrm{ha}$, but statistically not significantly different from the other treatments.

Keywords: cowpea, dry land, residual fertilizer

\section{PENDAHULUAN}

Peningkatan jumlah penduduk dan kebutuhan pangan nasional membuat kebutuhan lahan untuk pengembangan pertanian semakin meningkat. Akan tetapi, lahan pertanian subur semakin terbatas sehingga untuk memenuhi kebutuhan pangan nasional harus bergeser dengan memanfaatkan lahan suboptimal. Salah satu lahan suboptimal yang dapat

Balai Penelitian Tanaman Aneka Kacang dan Umbi, Jl. Raya Kendalpayak KM 8 Kotak Pos 66 Malang 65101

*Penulis Korespondensi: Email: estawinasa@gmail.com digunakan adalah lahan kering (Mulyani \& Sarwani 2013). Lahan kering adalah lahan yang digunakan untuk budi daya tanaman dan tidak pernah digenangi atau tergenang air pada sebagian besar waktu dalam setahun (Wahyunto \& Shofiyati 2013). Berdasarkan data BPS, Indonesia memiliki luas daratan 191,09 juta ha, sekitar 95,81 juta ha yang potensial untuk pertanian, yang terdiri atas 70,59 juta ha di lahan kering, 5,23 juta ha di lahan basah nonrawa, dan 19,99 juta ha di lahan rawa (Kementerian Pertanian 2015).

Kacang tunggak (Vigna unguiculata L. Walp.) merupakan salah satu tanaman penting karena dapat memperbaiki nitrogen di atmosfer dan berkontribusi 
pada perbaikan kesuburan tanah, khususnya dalam sistem pertanian skala kecil jika sedikit atau tidak ada pupuk yang diaplikasikan. Tanaman kacang tunggak toleran terhadap kekeringan dan dapat beradaptasi pada lingkungan yang penuh tekanan di mana biasanya tanaman lain tidak dapat tumbuh dengan baik (Bisikwa et al 2014; Ddamulira et al. 2015; da Silva \& Santos 2016). Oleh karena itu, kacang tunggak dapat dikembangkan di lahan kering iklim kering di Pulau Jawa dan luar Jawa, khususnya kawasan timur Indonesia (Nusa Tenggara Timur), di mana pada umumnya petani jarang memberi pupuk pada tanaman kacang tunggak.

Beberapa penelitian memperlihatkan bahwa aplikasi pupuk organik maupun anorganik dapat menyisakan residu pada tanah. Residu pupuk kandang kambing dapat meningkatkan produksi daun kacang tunggak yang berarti akan meningkatkan penerimaan cahaya matahari serta akan meningkatkan fotoasimilat yang dapat meningkatkan hasil biji kacang tunggak (Imthiyas \& Seran 2017). Residu pupuk NPK dapat memberikan pengaruh positif pada kandungan unsur hara dan pertumbuhan tanaman serta aktivitas mikrob di dalam tanah jika diberikan dalam dosis yang sesuai (Robertson \& Vitousek 2009). Efek residu pupuk organik pada tanaman cabai di pertanaman pertama dapat memperlihatkan pertumbuhan dan hasil tanaman kacang tunggak yang baik, bahkan tanpa perlu penambahan pupuk. Hal tersebut juga dapat membantu menjaga kesuburan tanah (Babaji et al. 2010). Residu $300 \mathrm{~kg}$ Phonska/ha atau dengan $3000 \mathrm{~kg}$ pupuk kandang sapi/ha (Lestari et al. 2018) maupun aplikasi $5000 \mathrm{~kg}$ pupuk kandang/ha memberikan hasil tertinggi pada pertanaman kacang tunggak dan residunya pada tanaman kedelai dibandingkan dengan aplikasi $300 \mathrm{~kg}$ Phonska/ha $\left(15 \% \mathrm{~N}, 15 \% \mathrm{P}_{2} \mathrm{O}_{5}, 15 \% \mathrm{~K}_{2} \mathrm{O}, 10 \% \mathrm{~S}\right)$ (Kuntyastuti \& Muzaiyanah 2017).

Tujuan penelitian ini adalah untuk mengetahui pengaruh residu pupuk dan bekas jarak tanam kacang hijau pertanaman pertama pada pertumbuhan dan hasil kacang tunggak pertanaman kedua di lahan kering.

\section{METODE PENELITIAN}

Penelitian dilaksanakan di lahan kering Alfisol pada musim kemarau (MK) tahun 2015 di Instalasi Penelitian dan Pengkajian Teknologi Pertanian (IP2TP) Muneng, Probolinggo, Jawa Timur. Benih kacang tunggak varietas KT 5 ditanam pada petak berukuran $4 \mathrm{~m}$ x 4,5 $\mathrm{m}$ dengan jarak tanam $40 \mathrm{~cm} \times 15 \mathrm{~cm}, 2$ tanaman/lubang. Percobaan ini merupakan penanaman kedua setelah tanaman kacang hijau, tanpa penambahan pupuk (pupuk perlakuan hanya diberikan pada tanaman pertama, yaitu kacang hijau). Percobaan dirancang menggunakan petak terpisah dengan tiga ulangan. Petak utama adalah bekas jarak tanam kacang hijau, yaitu 1) bekas jarak tanam $40 \mathrm{~cm} \times 10$ $\mathrm{cm}$, satu tanaman/lubang $(\mathrm{J} 1) ; 2)$ bekas jarak tanam 40 $\mathrm{cm} \times 15 \mathrm{~cm}$, dua tanaman/lubang (J2); dan 3) bekas jarak tanam $40 \mathrm{~cm} \times 20 \mathrm{~cm}$, dua tanaman/lubang (J3). Anak petak adalah residu kombinasi pupuk organik dan anorganik, yaitu: 1) residu tanpa pupuk (R0); 2) residu pemupukan $50 \mathrm{~kg} \mathrm{ZA}+50 \mathrm{~kg} \mathrm{SP}-36+100 \mathrm{~kg} \mathrm{KCl} / \mathrm{ha}$ (R1); 3) residu pemupukan $150 \mathrm{~kg}$ Phonska/ha (R2); 4) residu pemupukan $5000 \mathrm{~kg}$ pupuk kandang/ha (R3); dan 5) residu pemupukan $75 \mathrm{~kg}$ Phonska $+2500 \mathrm{~kg}$ pupuk kandang/ha (R4).

Pemeliharaan tanaman dilakukan secara intensif yang meliputi pengairan, penyiangan gulma, dan penyemprotan insektisida. Pengamatan yang dilakukan adalah analisis kimia tanah sebelum tanam kacang tunggak (setelah panen kacang hijau); penetrasi radiasi matahari di bawah dan di antara kanopi tanaman pada umur 20, 27, 35, 43, 48, dan 57 HST; bobot kering brangkasan dan tinggi tanaman umur 35 HST (sebelum masuk fase vegetatif); analisis kandungan hara pada brangkasan umur 35 HST, brangkasan dan biji saat panen; serta hasil dan komponen hasil (jumlah polong isi, bobot 100 biji, dan produksi biomas panen). Data dianalisis menggunakan sidik ragam dan ketika terdapat pengaruh yang berbeda nyata dilakukan uji beda nyata terkecil (BNT) pada taraf $5 \%$.

\section{HASIL DAN PEMBAHASAN}

\section{Kesuburan Tanah}

Setelah tanaman kacang hijau dipanen dan sebelum tanam kacang tunggak, dilakukan pengambilan contoh tanah komposit untuk analisis sifat kimia tanah (Tabel 1). Berdasarkan hasil analisis, lahan yang telah digunakan pada pertanaman pertama kacang hijau dengan jarak tanam $40 \mathrm{~cm}$ x 10-20 cm, 1-2 tanaman/ rumpun, tanpa atau dengan pemupukan dapat menurunkan $\mathrm{pH}$ tanah. Penerapan jarak tanam $40 \mathrm{~cm} \times 20$ $\mathrm{cm}, 2$ tanaman/rumpun (J3) ternyata dapat menurunkan $\mathrm{pH}$ tanah dari 8 menjadi 6,9 dan kadar $\mathrm{N}$-total dari 0,070 menjadi $0,036 \%$ dibanding penerapan jarak tanam $40 \mathrm{~cm} \times 10-15 \mathrm{~cm}, 1-2$ tanaman/rumpun (J1 dan J2).

Residu dari pemupukan $50 \mathrm{~kg}$ ZA + $50 \mathrm{~kg} \mathrm{SP-36} \mathrm{+}$ $100 \mathrm{~kg} \mathrm{KCl} / \mathrm{ha}$ (R1) pada tanaman kacang hijau di lahan kering iklim kering tanah Alfisol Probolinggo dapat menurunkan kualitas lahan berupa penurunan kadar C-organik dari 0,77 menjadi 0,56\%, N-total dari 0,07 menjadi $0,045 \%$, K-dd dari 0,6 menjadi 0,23 $\mathrm{Cmol}^{+} / \mathrm{kg}$, Ca-dd dari 16 menjadi $4,18 \mathrm{Cmol}^{+} / \mathrm{kg}$, dan Mg-dd dari 6,53 menjadi $0,48 \mathrm{Cmol}^{+} / \mathrm{kg}$, tetapi meningkatkan kadar P-tersedia dari 82,9 menjadi 110,1 ppm (Tabel 1). Residu dari aplikasi pupuk $150 \mathrm{~kg}$ Phonska/ha (R2) atau $5000 \mathrm{~kg}$ pupuk kandang/ha (R3), dapat mempertahankan kadar C-organik sekaligus meningkatkan kadar $\mathrm{N}$-total, $\mathrm{P}$-tersedia, dan $\mathrm{P}_{2} \mathrm{O}_{5}$ total dibanding tanpa pemupukan, namun masih tetap menurunkan kadar K-dd, Ca-dd, dan Mg-dd. Sebaliknya, residu penggunaan $75 \mathrm{~kg}$ Phonska $+2500 \mathrm{~kg}$ pupuk kandang/ha (R4) tidak dapat mempertahankan kadar C-organik, tetapi masih dapat meningkatkan kadar $\mathrm{P}$ - 
Tabel 1 Pengaruh jarak tanam dan pupuk pada sifat kimia tanah setelah panen kacang hijau sebelum tanam kacang tunggak di lahan kering iklim kering tanah Alfisol Probolinggo, 2015

\begin{tabular}{|c|c|c|c|c|c|c|c|c|}
\hline Jarak tanam & $\mathrm{pH} \mathrm{H}_{2} \mathrm{O}$ & $\mathrm{pH} \mathrm{KCl}$ & C-org & $\mathrm{N}$-total & $\begin{array}{c}\mathrm{P}_{2} \mathrm{O}_{5} \\
\text { Bray-1 }\end{array}$ & $\begin{array}{l}\mathrm{P}_{2} \mathrm{O}_{5} \\
\text { total }\end{array}$ & $\begin{array}{l}\mathrm{K}_{2} \mathrm{O} \\
\text { total }\end{array}$ & K-dd \\
\hline & & & $\%$ & $\%$ & ppm & \multicolumn{2}{|c|}{$\mathrm{mg} / 100 \mathrm{~g}$} & $\mathrm{Cmol}^{+} / \mathrm{kg}$ \\
\hline $\begin{array}{l}\text { Sebelum tanam kacang } \\
\text { hijau }\end{array}$ & 8,0 & 6,8 & 0,77 & 0,070 & 82,9 & - & - & 0,60 \\
\hline $40 \times 10,1 \mathrm{tnm}(\mathrm{J} 1)$ & 7,5 & 5,9 & 0,75 & 0,045 & 118,4 & 181 & 599 & 0,23 \\
\hline $40 \times 15,2 \mathrm{tnm}(\mathrm{J} 2)$ & 7,5 & 6,0 & 0,46 & 0,052 & 116,0 & 180 & 577 & 0,23 \\
\hline $40 \times 20,2 \mathrm{tnm}(\mathrm{J} 3)$ & 6,9 & 6,0 & 0,74 & 0,036 & 103,7 & 176 & 552 & 0,24 \\
\hline Jarak tanam & \multicolumn{4}{|c|}{$\mathrm{Cmol}^{+} / \mathrm{kg}$} & \multicolumn{4}{|c|}{ ppm } \\
\hline $\begin{array}{l}\text { Sebelum tanam kacang } \\
\text { hijau }\end{array}$ & 16,0 & 6,53 & 0,00 & 0,10 & 5,61 & 0,27 & 5,96 & 59,6 \\
\hline $40 \times 10,1 \mathrm{tnm}(\mathrm{J} 1)$ & 3,92 & 0,47 & 0,00 & 0,24 & 6,35 & 2,26 & 5,33 & 1,76 \\
\hline $40 \times 15,2$ tnm (J2) & 4,21 & 0,46 & 0,00 & 0,11 & 3,76 & 1,64 & 4,74 & 1,21 \\
\hline $40 \times 20,2$ tnm (J3) & 4,92 & 0,52 & 0,00 & 0,15 & 3,87 & 1,52 & 4,66 & 1,20 \\
\hline Pupuk & $\mathrm{pH} \mathrm{H} \mathrm{H}_{2} \mathrm{O}$ & $\mathrm{pH} \mathrm{KCl}$ & $\begin{array}{c}\text { C-org } \\
\%\end{array}$ & $\begin{array}{c}\text { N-total } \\
\%\end{array}$ & $\begin{array}{c}\mathrm{P}_{2} \mathrm{O}_{5} \\
\text { Bray-1 } \\
\text { ppm }\end{array}$ & $\begin{array}{l}\mathrm{P}_{2} \mathrm{O}_{5} \\
\text { total } \\
\quad \mathrm{mg}\end{array}$ & $\begin{array}{l}\mathrm{K}_{2} \mathrm{O} \\
\text { total } \\
\mathrm{g}\end{array}$ & $\begin{array}{c}\mathrm{K}-\mathrm{dd} \\
\mathrm{Cmol}^{+} / \mathrm{kg}\end{array}$ \\
\hline $\begin{array}{l}\text { Sebelum tanam kacang } \\
\text { hijau }\end{array}$ & 8,0 & 6,8 & 0,77 & 0,070 & 82,9 & - & - & 0,60 \\
\hline Tanpa pupuk (R0) & 7,5 & 5,9 & 0,55 & 0,035 & 112,0 & 162 & 595 & 0,22 \\
\hline NPK (R1) & 7,2 & 5,9 & 0,56 & 0,045 & 110,1 & 187 & 548 & 0,23 \\
\hline Phonska (R2) & 7,3 & 6,0 & 0,81 & 0,045 & 119,7 & 184 & 571 & 0,23 \\
\hline Pupuk kandang (R3) & 7,3 & 6,1 & 0,94 & 0,042 & 109,0 & 178 & 554 & 0,24 \\
\hline $\begin{array}{l}\text { Phonska+pupuk } \\
\text { kandang (R4) }\end{array}$ & 7,3 & 6,0 & 0,38 & 0,055 & 112,7 & 183 & 612 & 0,23 \\
\hline Rata-rata & 7,3 & 6,0 & 0,65 & 0,044 & 112,7 & 179 & 576 & 0,23 \\
\hline Pupuk & \multicolumn{4}{|c|}{$\mathrm{Cmol}^{+} / \mathrm{kg}$} & \multicolumn{4}{|c|}{ ppm } \\
\hline $\begin{array}{l}\text { Sebelum tanam kacang } \\
\text { hijau }\end{array}$ & 16,0 & 6,53 & 0,00 & 0,10 & 5,61 & 0,27 & 5,96 & 59,6 \\
\hline Tanpa pupuk (R0) & 4,20 & 0,49 & 0,00 & 0,28 & 4,88 & 2,24 & 4,85 & 1,32 \\
\hline NPK (R1) & 4,18 & 0,48 & 0,00 & 0,21 & 4,20 & 1,75 & 5,17 & 1,38 \\
\hline Phonska (R2) & 4,51 & 0,50 & 0,00 & 0,11 & 3,84 & 1,68 & 4,85 & 1,42 \\
\hline $\begin{array}{l}\text { Pupuk kandang (R3) } \\
\text { Phonska+pupuk }\end{array}$ & 4,44 & 0,46 & 0,00 & 0,11 & 3,77 & 1,70 & 4,87 & 1,33 \\
\hline kandang (R4) & 4,43 & 0,48 & 0,00 & 0,11 & 6,62 & 1,66 & 4,81 & 1,49 \\
\hline Rata-rata & 4,35 & 0,48 & 0,00 & 0,17 & 4,66 & 1,81 & 4,91 & 1,39 \\
\hline
\end{tabular}

Sumber: Kuntyastuti \& Lestari (2016)

tersedia, kadar $\mathrm{N}$-total, dan $\mathrm{P}_{2} \mathrm{O}_{5}$-total dibanding tanpa pemupukan (R0). Dengan kata lain, penggunaan 150 $\mathrm{kg}$ Phonska/ha (R2), $5000 \mathrm{~kg}$ pupuk kandang/ha (R3), atau $75 \mathrm{~kg}$ Phonska $+2500 \mathrm{~kg}$ pupuk kandang/ha (R4) pada tanaman kacang hijau musim tanam pertama di lahan kering iklim kering dapat digunakan sebagai salah satu komponen teknologi untuk produksi biomas tanaman kacang tunggak musim tanam kedua, maupun konservasi lahan kering iklim kering.

\section{Penetrasi Radiasi Surya}

Pada penelitian kacang tunggak dilakukan pengukuran penetrasi radiasi surya ke permukaan tanah di bawah dan di antara kanopi daun. Pengaruh residu pupuk pada tanaman kacang hijau musim pertama pada penetrasi radiasi surya ke permukaan tanah di bawah atau di antara kanopi tanaman kacang tunggak menunjukkan adanya variasi pengukuran pada saat tanaman berumur 43 HST. Di bawah kanopi tanaman kacang tunggak pada pagi hari sampai dengan umur 35 HST, residu pupuk pada kacang hijau tidak mempengaruhi penetrasi radiasi surya ke permukaan tanah, $\pm 80 \%$ pada umur $20 \mathrm{HST}$ menjadi $\pm 25 \%$ pada umur 35 HST (Gambar 1 kiri). Pada umur 43 HST, penetrasi radiasi surya ke permukaan tanah tertinggi diperoleh pada residu pupuk $75 \mathrm{~kg}$ Phonska $+2500 \mathrm{~kg}$ pupuk kandang/ha (R4), berubah menjadi residu 150 $\mathrm{kg}$ Phonska/ha (R2) di akhir pertumbuhan sampai menjelang panen. Daun kacang tunggak yang kecil, panjang, dan saling menutup ternyata menghalangi penetrasi radiasi surya ke permukaan tanah di bawah kanopi pada siang hari. Pola penetrasi hampir sama di antara perlakuan residu pupuk, tidak sampai $40 \%$ pada umur $20 \mathrm{HST}$ dan hanya $10 \%$ pada saat menjelang panen. Pada sore hari, rata-rata penetrasi radiasi surya ke permukaan tanah pada umur $20 \mathrm{HST}$ hampir $60 \%$, dan terus berkurang sampai saat menjelang panen, yaitu $<25 \%$. Pada umur 43 HST, adanya residu 5000 
kg pupuk kandang/ha (R3) membuat penetrasi radiasi surya lebih tinggi dibanding residu pupuk lainnya.

Di antara baris atau kanopi tanaman kacang tunggak, penetrasi radiasi surya yang sampai ke permukaan tanah di pagi hari sangat fluktuatif sejak umur 20 HST $( \pm 70 \%)$ sampai menjelang panen (>30\%). Rata-rata penetrasi radiasi surya ke permukaan tanah tertinggi diperoleh apabila ada residu $150 \mathrm{~kg}$ Phonska/ha (R2) (Gambar 1b). Pada siang hari pada umur 20 HST, penetrasi radiasi surya ke permukaan tanah mencapai $100 \%$. Selanjutnya berkurang dengan pola serupa di antara perlakuan residu pupuk sampai saat menjelang panen $( \pm 30 \%)$. Pada sore hari, penetrasi radiasi surya ke permukaan tanah pada umur 20 HST hampir 100\%, kemudian berkurang dan hanya $\pm 35 \%$ pada saat menjelang panen. Penetrasi radiasi surya ke permukaan tanah di antara kanopi tanaman tanpa residu pupuk (R0) pada umur 43 HST lebih tinggi dibanding bila ada residu pupuk.

Di bawah kanopi pada umur 20 HST di siang hari, penetrasi radiasi surya ke permukaan tanah sangat rendah, $\pm 32 \%$ pada umur $20 \mathrm{HST}$, kemudian naik turun, maksimal $40 \%$, dan $\pm 18 \%$ menjelang panen (Gambar 2a). Penetrasi radiasi surya pada bekas jarak tanam $40 \mathrm{~cm} \times 20 \mathrm{~cm}, 2$ tanaman/rumpun (J3) lebih tinggi dibanding jarak tanam lainnya. Daun kacang tunggak yang kecil, panjang, dan saling menutup berpeluang besar menghalangi penetrasi radiasi surya ke permukaan tanah.

Di antara baris atau kanopi tanaman, penetrasi radiasi surya ke permukaan tanah pada siang hari masih $100 \%$, berkurang menjadi $30-40 \%$ pada umur $43 \mathrm{HST}$, dan semakin menurun pada saat menjelang panen (Gambar 2b). Pola penetrasi radiasi surya pada bekas ketiga jarak tanam hampir sama.

\section{Pertumbuhan, Komponen Hasil, dan Hasil}

Setelah panen tanaman kacang hijau, diperoleh variasi kesuburan tanah di antara bekas ketiga jarak tanam (Tabel 1). Kondisi tersebut ternyata tidak mengakibatkan perbedaan keragaan tanaman kacang tunggak yang ditanam setelah kacang hijau. Tanaman kacang tunggak varietas KT-5 sebagai tanaman indikator untuk mengevalusi pengaruh residu pupuk pada tanaman kacang hijau, dapat tumbuh dan berkembang serta membentuk polong dengan cukup baik. Akan tetapi, pada saat tanaman mencapai umur 36 HST, kanopi di antara baris tanaman belum menutup. Kegiatan panen harus dilakukan dua kali, pertama pada saat tanaman berumur 68 HST dan kedua pada saat tanaman berumur 86 HST.

Dengan keragaan pertumbuhan yang baik, ternyata bekas tiga jarak tanam atau tata letak tanaman pada kacang hijau tidak mempengaruhi pertumbuhan, hasil
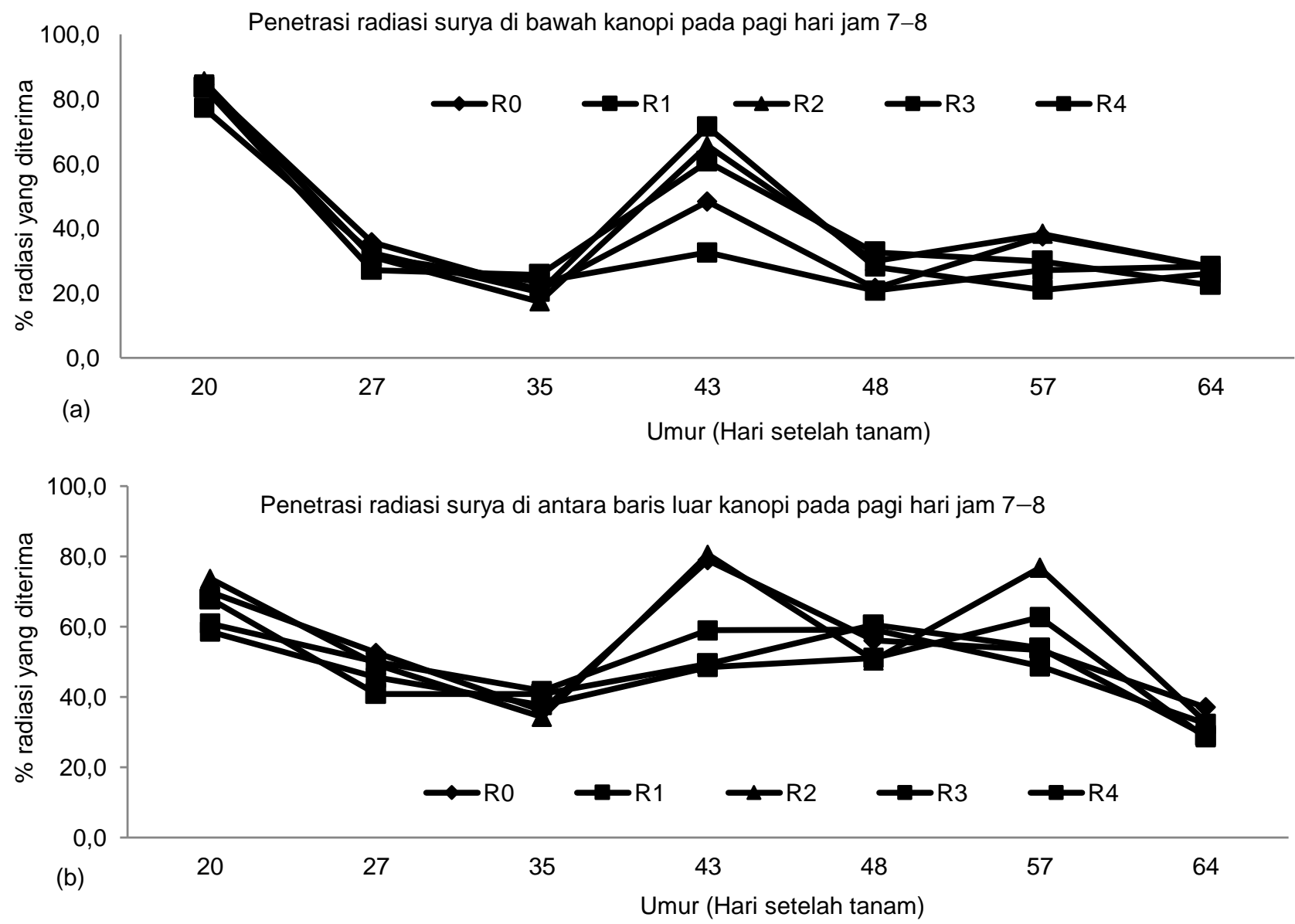

Gambar 1 Penetrasi radiasi surya di bawah dan di antara kanopi kacang tunggak varietas KT-5 pada pagi hari di lahan kering iklim kering tanah Alfisol Probolinggo. 

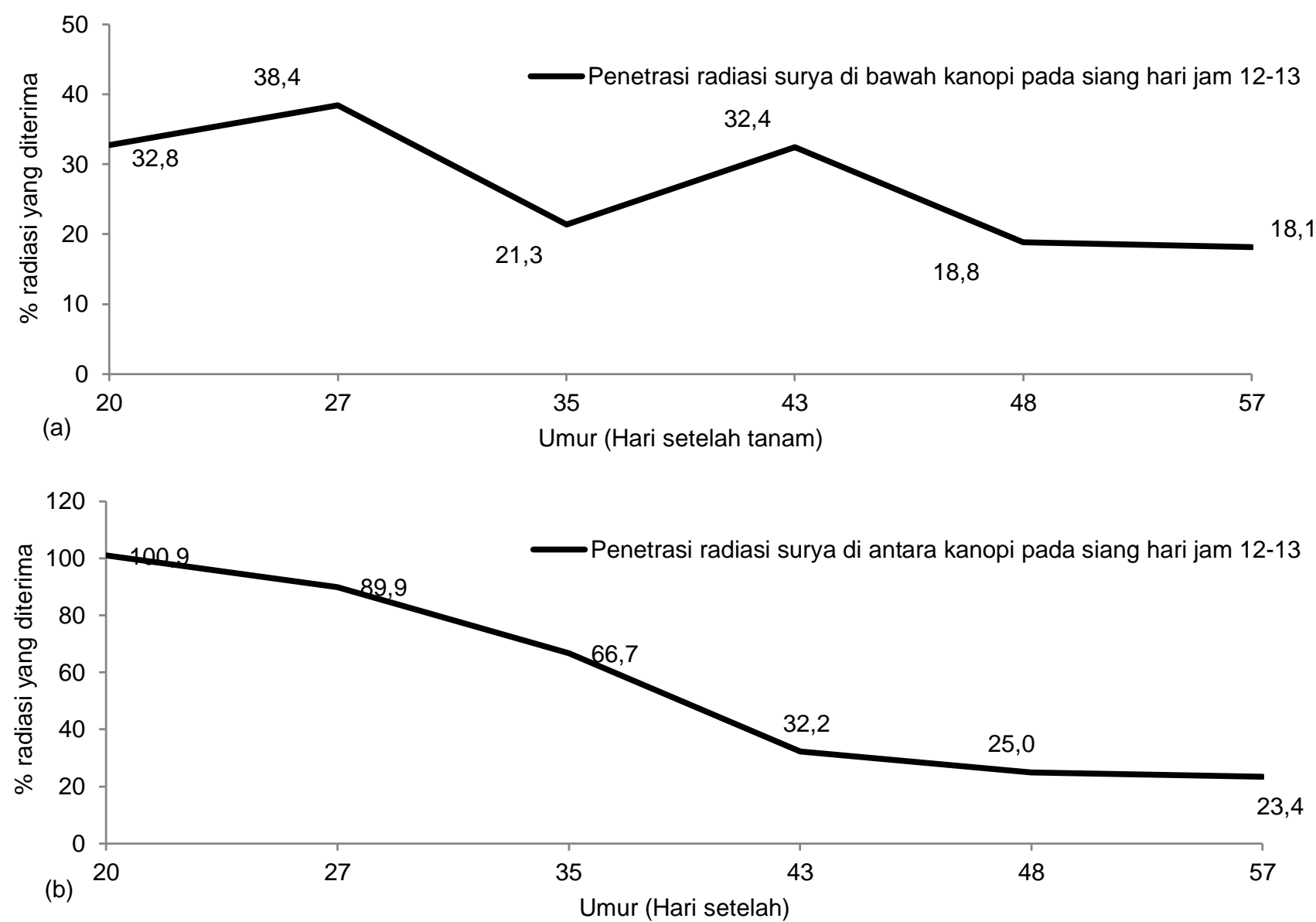

Gambar 2 Penetrasi radiasi surya di bawah dan di antara kanopi kacang tunggak varietas KT-5 pada siang hari di lahan kering iklim kering tanah Alfisol Probolinggo.

biji, dan komponen hasil kacang tunggak varietas KT5 (Tabel 2 dan 3). Sebaliknya, residu pupuk organik dan anorganik pada kacang hijau dapat mempengaruhi pertumbuhan, walaupun hanya bobot kering akar dan tajuk tanaman kacang tunggak umur $35 \mathrm{HST}$. Interaksi antara bekas tata letak tanaman kacang hijau dan residu pupuk pada kacang hijau tidak memberikan pengaruh nyata pada pertumbuhan, komponen hasil, dan hasil kacang tunggak (Tabel 2 dan 3).

Hasil penelitian Teixeira et al. (2016) menyatakan bahwa efek residu perlakuan pupuk NK + kapur dan residu pupuk NK menunjukkan hasil yang lebih baik pada hasil biji, jumlah polong isi per tanaman, jumlah biji per polong, dan bobot kering tanaman kacang tunggak. Efek residu perlakuan pupuk NPK menunjukkan hasil terbaik pada bobot 100 biji. Pada penelitian ini, residu $5000 \mathrm{~kg}$ pupuk kandang/ha (R3) dan 75 $\mathrm{kg}$ Phonska $+2500 \mathrm{~kg}$ pupuk kandang/ha (R4) dapat memperbaiki perkembangan akar $25 \%$ dibanding tanpa residu pupuk. Residu $50 \mathrm{~kg} Z \mathrm{ZA}+50 \mathrm{~kg} \mathrm{SP}-36+$ $100 \mathrm{~kg} \mathrm{KCl} / \mathrm{ha}$ (R1), $150 \mathrm{~kg}$ Phonska/ha (R2), dan 5000 $\mathrm{kg}$ pupuk kandang/ha (R3) dapat memperbaiki perkembangan tajuk tanaman kacang tunggak sebesar 30-39\% dibanding tanpa residu pupuk (R0). Walaupun residu pupuk dapat memperbaiki perkembangan akar dan tajuk, ternyata tinggi tanaman tidak terpengaruh. Tanaman kacang tunggak mencapai tinggi $30 \mathrm{~cm}$ pada umur $35 \mathrm{HST}, 59 \mathrm{~cm}$ pada saat panen (Tabel 2), dan membentuk 5,8 polong isi/tanaman dengan bobot 100 biji 13,86 g (Tabel 3). Pertumbuhan tersebut dapat menunjang pencapaian produktivitas biji 1,58 t/ha dengan produksi biomas panen 5,69 t/ha. Biomas panen ditimbang pada saat panen dilaksanakan. Produksi biomas panen kacang hijau varietas Vima-1 rata-rata 2,97 t/ha (Kuntyastuti dan Lestari 2016), hanya $52 \%$ dari produksi biomas panen kacang tunggak. Biomas panen kacang tunggak dapat dimanfaatkan terutama untuk pakan ternak. Dengan kata lain, pada lahan kering iklim kering, budi daya kacang tunggak dapat memenuhi kebutuhan protein nabati untuk manusia sekaligus kebutuhan pakan untuk ternak.

Residu pemupukan dari pertanaman pertama kacang hijau tidak memberikan pengaruh nyata pada hasil biji pertanaman kedua kacang tunggak. Hasil yang tidak berbeda ini diduga disebabkan oleh tidak terpenuhinya kebutuhan hara tanaman yang terlihat dari kadar unsur hara $\mathrm{N}$ pada brangkasan umur 35 HST dan brangkasan panen yang tergolong kategori rendah dan kadar unsur hara $\mathrm{P}$ dan $\mathrm{K}$ yang tergolong kategori cukup. Pupuk yang diberikan pada saat pertanaman pertama sudah diserap semua oleh tanaman kacang hijau sehingga tidak ada lagi yang bisa digunakan untuk pertanaman kedua kacang tunggak. 
Tabel 2 Pengaruh bekas jarak tanam dan residu pupuk kacang hijau pada pertumbuhan tanaman kacang tunggak varietas KT-5 di lahan kering iklim kering tanah Alfisol Probolinggo

\begin{tabular}{|c|c|c|c|c|}
\hline Perlakuan & $\begin{array}{l}\text { Bobot kering } \\
\text { akar }(\mathrm{g} / \mathrm{tnm})\end{array}$ & $\begin{array}{l}\text { Bobot kering } \\
\text { tajuk (g/tnm) }\end{array}$ & $\begin{array}{c}\text { Tinggi tanaman } \\
\text { umur } 35 \text { HST }\end{array}$ & $\begin{array}{c}\text { Tinggi tanaman } \\
\text { umur } 68 \mathrm{HST} \\
\text { (panen) }\end{array}$ \\
\hline \multicolumn{5}{|l|}{ Bekas jarak tanam (cm) } \\
\hline $40 \times 10,1$ tnm/rumpun (J1) & 0,24 a & 2,43 a & $29,1^{\text {a }}$ & $60,4^{a}$ \\
\hline $40 \times 15,2$ tnm/rumpun (J2) & 0,25 a & $2,77^{a}$ & 30,2 a & 57,0 a \\
\hline $40 \times 20,2$ tnm/rumpun (J3) & 0,25 a & 2,65 a & 29,7 a & 59,6 a \\
\hline \multicolumn{5}{|l|}{ Residu pemupukan (kg/ha) } \\
\hline Tanpa pupuk (R0) & $0,21 \mathrm{~b}$ & $2,10^{b}$ & 28,8 a & 57,7 a \\
\hline $50 \mathrm{ZA}+50 \mathrm{SP} 36+100 \mathrm{KCl}(\mathrm{R} 1)$ & $0,23 a b$ & 2,73 a & $30,1^{\text {a }}$ & $58,8^{a}$ \\
\hline 150 Phonska (R2) & $0,25 \mathrm{ab}$ & 2,76 a & 31,4 a & 58,1 a \\
\hline 5000 pupuk kandang (R3) & $0,27^{a}$ & 2,91 a & 29,3 a & 59,9 a \\
\hline $\begin{array}{l}75 \text { Phonska+2500 pupuk kandang } \\
\text { (R4) }\end{array}$ & 0,26 a & $2,57 \mathrm{ab}$ & 28,9 a & $60,5^{a}$ \\
\hline Rata-rata & 0,24 & 2,62 & 29,7 & 59,0 \\
\hline Interaksi & tn & tn & tn & tn \\
\hline $\mathrm{KK}(\%)$ & 17,57 & 11,66 & 18,91 & 18,23 \\
\hline
\end{tabular}

Tabel 3 Pengaruh bekas jarak tanam dan residu pupuk kacang hijau pada komponen hasil dan hasil biji kacang tunggak varietas KT-5 di lahan kering iklim kering tanah Alfisol Probolinggo

\begin{tabular}{|c|c|c|c|c|}
\hline Perlakuan & $\begin{array}{c}\text { Jumlah polong } \\
\text { isi/tnm }\end{array}$ & $\begin{array}{l}\text { Bobot } 100 \\
\text { biji }(g)\end{array}$ & $\begin{array}{c}\text { Hasil biji kadar air } \\
12 \%(\mathrm{t} / \mathrm{ha})\end{array}$ & $\begin{array}{l}\text { Produksi biomas } \\
\text { panen }(\mathrm{t} / \mathrm{ha})\end{array}$ \\
\hline \multicolumn{5}{|l|}{ Bekas jarak tanam $(\mathrm{cm})$} \\
\hline $40 \times 10,1$ tnm/rumpun (J1) & 5,5 a & 13,82 a & 1,56 a & 6,05 a \\
\hline $40 \times 15,2$ tnm/rumpun (J2) & 6,1 a & 13,80 a & 1,57 a & 5,63 a \\
\hline $40 \times 20,2$ tnm/rumpun (J3) & 5,6 a & 13,96 a & 1,62 a & 5,39 a \\
\hline \multicolumn{5}{|l|}{ Residu pemupukan (kg/ha) } \\
\hline Tanpa pupuk (R0) & 6,0 a & 14,05 a & 1,58 a & 5,24 a \\
\hline $50 \mathrm{ZA}+50 \mathrm{SP} 36+100 \mathrm{KCl}(\mathrm{R} 1)$ & 5,8 a & 13,85 a & 1,54 a & 5,65 a \\
\hline 150 Phonska (R2) & 5,9 a & 13,78 a & 1,60 a & 5,78 a \\
\hline 5000 pupuk kandang (R3) & 6,1 a & 13,68 a & 1,58 a & 5,92 a \\
\hline $\begin{array}{l}75 \text { Phonska+2500 pupuk kandang } \\
\text { (R4) }\end{array}$ & 5,0 a & 13,92 a & 1,62 a & 5,84 a \\
\hline Rata-rata & 5,8 & 13,86 & 1,58 & 5,69 \\
\hline Interaksi & tn & tn & tn & tn \\
\hline $\mathrm{KK}(\%)$ & 11,18 & 4,43 & 8,54 & 13,35 \\
\hline
\end{tabular}

\section{Kadar dan Serapan Unsur Hara Biji dan Brangkasan Tanaman}

Hubungan antara kandungan total hara dan produksi tanaman kedelai menunjukkan bahwa penurunan produktivitas tanaman kedelai disebabkan oleh penurunan kadar hara dalam jaringan maupun ketersediaan hara dalam tanah untuk proses pertumbuhan dan produksi (Bachtiar et al. 2016). Diharapkan, peningkatan kadar dan serapan hara N, P, dan K pada tanaman dan biji kacang tunggak akan meningkatkan pula hasil biji pada tanaman kacang tunggak.

Residu pupuk pada kacang hijau dapat meningkatkan kadar dan serapan unsur hara NPK pada brangkasan tanaman kacang tunggak umur $35 \mathrm{HST}$. Residu pupuk $50 \mathrm{~kg} \mathrm{ZA}+50 \mathrm{~kg} \mathrm{SP} 36+100 \mathrm{~kg} \mathrm{KCl} / \mathrm{ha}(\mathrm{R} 1)$ dapat meningkatkan kadar unsur $\mathrm{K}$ dari $2,36 \%$ menjadi $2,79 \%$ (meningkat $18 \%$ dan tertinggi) dan serapan $\mathrm{K}$ dari 49,87 mg K/tanaman menjadi 76,03 mg K/tanaman (meningkat $52 \%$ dan tertinggi) dibanding tanpa residu pupuk (R0). Residu $5000 \mathrm{~kg}$ pupuk kandang/ha (R3) meningkatkan kadar $\mathrm{N}$ dari $2,77 \%$ menjadi 2,90\% (meningkat $5 \%$ ) dan serapan $\mathrm{N}$ dari $58,56 \mathrm{mg} \mathrm{N} /$ tanaman menjadi 83,69 $\mathrm{mg} \mathrm{N} /$ tanaman (meningkat $43 \%$, tertinggi), serta serapan $P$ dari $10,99 \mathrm{mg} P /$ tanaman menjadi $13,95 \mathrm{mg} \mathrm{P} /$ tanaman (meningkat $27 \%$, tertinggi) dibanding tanpa residu pupuk (R0) (Tabel 4). Chemining'wa et al. (2018) melaporkan bahwa serapan hara $P$ tertinggi pada biji kacang tunggak $(6 \mathrm{~kg} / \mathrm{ha})$ diperoleh pada tanaman kacang tunggak yang diberi pupuk $P$ sebanyak $50 \mathrm{~kg} / \mathrm{ha}$. Mutu biji kacang tunggak juga terpengaruh oleh perbedaan bekas jarak tanam dan residu pupuk pada tanaman kacang hijau. Pada lahan bekas tanaman kacang hijau dengan jarak tanam $40 \mathrm{~cm} \times 15-20 \mathrm{~cm}, 2$ tanaman/ rumpun (J2 dan J3) kemudian ditanami kacang tunggak, dapat dihasilkan biji dengan kadar dan serapan 
unsur $\mathrm{N}$ dan $\mathrm{K}$ yang lebih tinggi dibanding bekas jarak tanam $40 \mathrm{~cm} \times 10 \mathrm{~cm}, 1$ tanaman/rumpun (J1).

Akumulasi unsur $\mathrm{N}$ dan $\mathrm{P}$ tertinggi dalam brangkasan kacang tunggak umur 35 HST juga diperoleh pada lahan dengan residu pupuk kandang $5000 \mathrm{~kg} / \mathrm{ha}$ (R3) (Tabel 4). Biji kacang tunggak dengan kadar $\mathrm{N}$ $1,89 \%$ (tertinggi) dan mengakumulasi $\mathrm{N}$ dalam biji sebanyak $112,52 \mathrm{~kg} \mathrm{~N} / \mathrm{ha}$ (tertinggi) dapat diperoleh apabila kacang tunggak varietas KT-5 ditanam pada lahan dengan perlakuan setelah tanaman kacang hijau diberi pupuk $5000 \mathrm{~kg}$ pupuk kandang/ha (R3) (Tabel 5). Hal tersebut juga sejalan dengan kadar dan serapan unsur hara pada brangkasan panen di lahan dengan residu $5000 \mathrm{~kg}$ pupuk kandang/ha (R3), di mana brangkasan kacang tunggak mengandung 2,64\% N (tertinggi) dan juga $0,54 \% \mathrm{P}$ (tertinggi), serta mengakumulasi unsur $\mathrm{N}$ dan $\mathrm{P}$ tertinggi dalam brangkasan, yaitu 40,97 kg N/ha dan 8,32 kg P/ha (Tabel 6). Walaupun pemberian $5000 \mathrm{~kg}$ pupuk kandang/ha tidak dapat meningkatkan hasil biji kacang hijau varietas Vima-1 (Kuntyastuti \& Lestari 2016), pemberian tersebut dapat mengkonservasi lahan kering dengan mempertahankan atau meningkatkan kesuburan tanah melalui peningkatan kadar C-organik, P-tersedia, dan P-total (Tabel 1). Pengaruh baik ini terus berlanjut sampai ke perbaikan mutu brangkasan dan biji kacang tunggak. Informasi ini menambah informasi yang telah lama dan sering disampaikan bahwa pupuk organik dapat mempertahankan dan meningkatkan hasil tanaman sekaligus mempertahankan dan memperbaiki kualitas tanah atau lahan pertanian di daerah beriklim kering.

Potensi produksi biomas panen kacang tunggak yang dibudidayakan di lahan kering iklim kering cukup menjanjikan. Biomas panen kacang tunggak kahat unsur $\mathrm{N}$, tetapi masih cukup mengandung unsur $\mathrm{P}$ dan $\mathrm{K}$ (Tabel 6). Berbeda dari pengaruhnya pada kadar dan serapan unsur NPK dalam brangkasan umur 35 HST dan biji kacang tunggak, ternyata kadar dan serapan unsur NPK tertinggi dalam biomas panen diperoleh pada kacang tunggak yang ditanam pada lahan bekas jarak tanam $40 \mathrm{~cm} \times 10 \mathrm{~cm}, 1$ tanaman/rumpun (J1). Pada lahan tersebut, biomas panen kacang tunggak mengandung $1,82 \% \mathrm{~N}, 0,38 \% \mathrm{P}$, dan $1,77 \% \mathrm{~K}$, dan mengakumulasi $109,88 \mathrm{~kg} \mathrm{~N} / \mathrm{ha}$ (lebih tinggi 16,33$20,43 \mathrm{~kg} \mathrm{~N} / \mathrm{ha}$ ), $23,23 \mathrm{~kg} \mathrm{P} / \mathrm{ha}$ (lebih tinggi 4,16-6,29 $\mathrm{kg} \mathrm{P} / \mathrm{ha}$ ), dan 106,76 kg K/ha (lebih tinggi 10,05-19,27 $\mathrm{kg} \mathrm{K} / \mathrm{ha}$ ) dibanding bekas dua jarak tanam lainnya. Sebaliknya, pengaruh residu pupuk pada kadar dan serapan unsur hara NPK dalam brangkasan 35 HST, biji, dan biomas panen kacang tunggak relatif lebih konsisten.

Tabel 4 Pengaruh bekas jarak tanah dan residu pupuk kacang hijau pada kadar dan serapan unsur hara dalam brangkasan kacang tunggak varietas KT-5 umur 35 HST di lahan kering iklim kering tanah Alfisol Probolinggo

\begin{tabular}{|c|c|c|c|c|c|c|}
\hline \multirow{2}{*}{ Perlakuan } & \multicolumn{3}{|c|}{ Kadar unsur hara (\%) } & \multicolumn{3}{|c|}{ Serapan unsur hara (mg/tnm) } \\
\hline & $\mathrm{N}$ & $\mathrm{P}$ & $\mathrm{K}$ & $\mathrm{N}$ & $\mathrm{P}$ & $\mathrm{K}$ \\
\hline \multicolumn{7}{|l|}{ Bekas jarak tanam $(\mathrm{cm})$} \\
\hline $40 \times 10,1$ tnm/rumpun (J1) & 2,72 & 0,48 & 2,30 & 66,68 & 11,70 & 56,09 \\
\hline $40 \times 15,2$ tnm/rumpun (J2) & 2,92 & 0,48 & 2,68 & 80,61 & 13,24 & 74,22 \\
\hline $40 \times 20,2$ tnm/rumpun (J3) & 2,93 & 0,48 & 2,45 & 76,61 & 12,68 & 65,25 \\
\hline \multicolumn{7}{|l|}{ Residu pemupukan (kg/ha) } \\
\hline Tanpa pupuk (R0) & 2,77 & 0,52 & 2,36 & 58,56 & 10,99 & 49,87 \\
\hline $50 \mathrm{ZA}+50 \mathrm{SP} 36+100 \mathrm{KCl}(\mathrm{R} 1)$ & 2.86 & 0,47 & 2.79 & 77,31 & 12.77 & 76.03 \\
\hline 150 Phonska (R2) & 2,89 & 0,48 & 2,67 & 79,66 & 13,14 & 73,71 \\
\hline 5000 pupuk kandang (R3) & 2,90 & 0,48 & 2,42 & 83,69 & 13,95 & 70,92 \\
\hline \multicolumn{7}{|l|}{75 Phonska+2500 pupuk kandana } \\
\hline (R4) & 2,88 & 0,46 & 2,15 & 73,94 & 11,83 & 55,38 \\
\hline Rata-rata & 2,86 & 0,48 & 2,48 & 74,63 & 12,54 & 65,18 \\
\hline Kategori & Rendah & Cukup & Cukup & & & \\
\hline
\end{tabular}

Tabel 5 Pengaruh bekas jarak tanam dan residu pupuk kacang hijau pada kadar dan serapan unsur hara dalam biji kacang tunggak varietas KT-5 di lahan kering iklim kering tanah Alfisol Probolinggo

\begin{tabular}{lcccccc}
\hline \multicolumn{1}{c}{ Perlakuan } & \multicolumn{2}{c}{ Kadar unsur hara (\%) } & \multicolumn{3}{c}{ Serapan unsur hara (kg/ha) } \\
& $\mathrm{N}$ & $\mathrm{P}$ & $\mathrm{K}$ & $\mathrm{N}$ & $\mathrm{P}$ & $\mathrm{K}$ \\
\hline Bekas jarak tanam (cm) & & & & & & \\
40 x 10, 1 tnm/rumpun (J1) & 2,46 & 0,53 & 1,37 & 37,67 & 8,15 & 21,10 \\
40 x 15, 2 tnm/rumpun (J2) & 2,56 & 0,53 & 1,60 & 39,31 & 8,20 & 24,66 \\
40 x 20, 2 tnm/rumpun (J3) & 2,57 & 0,51 & 1,62 & 40,65 & 8,08 & 25,71 \\
Residu pemupukan (kg/ha) & & & & & & \\
Tanpa pupuk (R0) & 2,54 & 0,53 & 1,60 & 39,37 & 8,15 & 24,83 \\
50 ZA+50 SP36+100 KCl (R1) & 2,51 & 0,54 & 1,44 & 37,86 & 8,18 & 21,79 \\
150 Phonska (R2) & 2,51 & 0,50 & 1,53 & 39,30 & 7,83 & 23,94 \\
5000 pupuk kandang (R3) & 2,64 & 0,54 & 1,58 & 40,97 & 8,32 & 24,54 \\
75 Phonska+2500 pupuk kandang (R4) & 2,43 & 0,52 & 1,51 & 38,55 & 8,23 & 24,03 \\
Rata-rata & 2,53 & 0,53 & 1,53 & 39,21 & 8,14 & 23,83 \\
\hline
\end{tabular}


Tabel 6 Pengaruh bekas jarak tanam dan residu pupuk kacang hijau pada kadar dan serapan unsur hara dalam brangkasan kacang tunggak varietas KT-5 saat panen di lahan kering iklim kering tanah Alfisol Probolinggo

\begin{tabular}{|c|c|c|c|c|c|c|}
\hline \multirow{2}{*}{ Perlakuan } & \multicolumn{3}{|c|}{ Kadar unsur hara (\%) } & \multicolumn{3}{|c|}{ Serapan unsur hara $(\mathrm{kg} / \mathrm{ha})$} \\
\hline & $\mathrm{N}$ & $\mathrm{P}$ & $\mathrm{K}$ & $\mathrm{N}$ & $\mathrm{P}$ & $\mathrm{K}$ \\
\hline \multicolumn{7}{|l|}{ Bekas jarak tanam (cm) } \\
\hline $40 \times 10,1$ tnm/rumpun (J1) & 1,82 & 0,38 & 1,77 & 109,88 & 23,23 & 106,76 \\
\hline 40 x 15, 2 tnm/rumpun (J2) & 1,68 & 0,34 & 1,76 & 93,55 & 19,07 & 96,71 \\
\hline 40 x 20, 2 tnm/rumpun (J3) & 1,69 & 0,32 & 1,66 & 89,45 & 16,94 & 87,49 \\
\hline \multicolumn{7}{|l|}{ Residu pemupukan (kg/ha) } \\
\hline Tanpa pupuk (R0) & 1,76 & 0,34 & 1,71 & 95,67 & 18,62 & 92,91 \\
\hline $50 \mathrm{ZA}+50 \mathrm{SP} 36+100 \mathrm{KCl}(\mathrm{R} 1)$ & 1,66 & 0,33 & 1,76 & 91,18 & 18,00 & 94,65 \\
\hline 150 Phonska (R2) & 1,52 & 0,31 & 1,70 & 87,84 & 18,01 & 98,78 \\
\hline 5000 pupuk kandang (R3) & 1,89 & 0,39 & 1,52 & 112,52 & 23,40 & 90,12 \\
\hline \multicolumn{7}{|l|}{75 Phonska+2500 pupuk kandang } \\
\hline \multirow[t]{2}{*}{ Rata-rata } & 1,73 & 0,35 & 1,73 & 97,63 & 19,75 & 96,99 \\
\hline & Rendah & Cukup & Cukup & & & \\
\hline
\end{tabular}

Kadar unsur $\mathrm{N}$ dan $\mathrm{P}$ tertinggi, yaitu $1,89 \% \mathrm{~N}$ dan $0,39 \% \mathrm{P}$ dan akumulasi tertinggi unsur $\mathrm{N}$ dan $\mathrm{P}$ dalam biomas panen, yaitu $112,52 \mathrm{~kg} \mathrm{~N} / \mathrm{ha}$ dan $23,40 \mathrm{~kg} \mathrm{P} / \mathrm{ha}$, diperoleh dari biomas panen kacang tunggak yang ditanam pada lahan dengan residu $5000 \mathrm{~kg}$ pupuk kandang/ha (R3). Kadar dan serapan unsur K tertinggi, yaitu $1,95 \% \mathrm{~K}$ dengan akumulasi $108,48 \mathrm{~kg} \mathrm{~K} / \mathrm{ha}$, diperoleh dari biomas panen pada lahan dengan residu $75 \mathrm{~kg}$ Phonska $+2500 \mathrm{~kg}$ pupuk kandang/ha (R4) (Tabel 6).

\section{KESIMPULAN}

Budi daya kacang tunggak di lahan dengan residu $5000 \mathrm{~kg}$ pupuk kandang/ha (R3) dan residu $75 \mathrm{~kg}$ Phonska $+2500 \mathrm{~kg}$ pupuk kandang/ha (R4) memberikan pengaruh nyata pada bobot kering akar dan tajuk. Hasil biji tertinggi diperoleh pada perlakuan J3 dan R4, yaitu sebesar 1,62 t/ha dan biomas tertinggi diperoleh pada perlakuan $\mathrm{J} 3$, yaitu sebesar $5,92 \mathrm{t} / \mathrm{ha}$, namun secara statistik tidak berbeda nyata dibandingkan dengan perlakuan lainnya. Lahan bekas jarak tanam $40 \mathrm{~cm} \times 10 \mathrm{~cm}, 1$ tanaman/rumpun (J1) yang ditanami kacang tunggak memperoleh produksi biomas panen dengan kadar dan akumulasi NPK tertinggi, yaitu $1,82 \% \mathrm{~N}, 0,38 \% \mathrm{P}$, dan $1,77 \% \mathrm{~K}$ dengan akumulasi 109,88 kg N/ha, 23,23 kg P/ha, dan 106,76 $\mathrm{kg} \mathrm{K} / \mathrm{ha}$ dibanding jarak tanam lain.

\section{DAFTAR PUSTAKA}

Babaji BA, Yahaya RA, Mahadi MA, Jaliya MM, Ajeigbe HA, Sharifai Al, Kura HN, Arunah OL, Ibrahim A. 2010. Response of cowpea [Vigna unguiculata (L.) Walp] to residual effect to different application rates of sheep manure on chili pepper (Capsicum annuum). Journal of Food, Agriculture, and Environment 8(2): 339-343.
Bachtiar, Ghulamahdi M, Melati M, Guntoro D, Sutandi A. 2016. Kecukupan hara fosfor pada pertumbuhan dan produksi kedelai dengan budidaya jenuh air di tanah mineral dan bergambut. Jurnal Ilmu Tanah dan Lingkungan 18(1): 21-27. https:// doi.org/10.29244/jitl.18.1.21-27

Bisikwa J, Kawooya R, Ssebuliba JM, Ddungu SO, Biruma M, Okello DK. 2014. Effects of plant density on the performance of local and elite cowpea varieties in Eastern Uganda. African Journal of Applied Agricultural Sciences and Technologies 1(1): 28-41.

Chemining'wa GN, Ngeno JK, Hutchinson MJ, Shibairo SL. 2018. Influence of $P$ fertilizer on nodulation, growth, and nutrient content of cowpea (Vigna unguiculata) in acidic soils of South Western Kenya. International Journal of Plant \& Soil Science 25(3): 1-12. https://doi.org/10.9734/IJPSS/2018/44765

Ddamulira G, Santos CAF, Obuo P, Alanyo M, Lwanga CK. 2015. Grain yield and protein content of Brazilian cowpea genotypes under diverse Ugandan environments. American Journal of Plant Sciences 6: 2074-2084. https://doi.org/10.4236/ ajps.2015.613208

Da Silva DOM, Santos CAF. 2016. Adaptability and stability parameters for potassium and calcium contents and grain yield in cowpea lines. African Journal of Agricultural Research 11(36): 3366-3374. https://doi.org/10.5897/AJAR2016. 11526

Imthiyas MSM, Seran TH. 2017. Residual effect of goat manure and expert fertilizer treated with proceeding crop of radish (Raphanus sativus L.) on succeeding crop of vegetable cowpea (Vigna unguiculata L.). Annals of Agricultural and Environmental Sciences 2(2): 1-5.

Kementerian Pertanian. 2015. Rencana Strategis Kementerian Pertanian Tahun 2015-2019. Biro Perencanaan, Sekretariat Jenderal. Jakarta (ID). 
Kuntyastuti H, Lestari SAD. 2016. Pengaruh interaksi antara dosis pupuk dan populasi tanaman terhadap pertumbuhan dan hasil kacang hijau pada lahan kering beriklim kering. Jurnal Penelitian Pertanian Tanaman Pangan 35(3): 239-249. https:// doi.org/10.21082/jpptp.v35n3.2016.p239-249

Kuntyastuti H, Muzaiyanah S. 2017. Effect of organic fertilizer and its residual on cowpea and soybean in acid soils. Journal of Degraded and Mining Land Management 5(1): 987-994. https://doi.org/ 10.15243/jdmlm.2017.051.987

Lestari SAD, Sutrisno, Kuntyastuti H. 2018. Pengaruh pupuk terhadap pertanaman kacang hijau dan residunya pada tanaman kacang tunggak. Jurnal IImu Pertanian Indonesia 23(1): 21-28. https:// doi.org/10.18343/jipi.23.1.21

Mulyani A, Sarwani M. 2013. Karakteristik dan potensi lahan sub optimal untuk pengembangan pertanian di Indonesia. Jurnal Sumberdaya Lahan 7(1): 47-55.

Robertson GP, Vitousek PM. 2009. Nitrogen in agriculture: balancing the cost of an essensial resource. Annual Review of Environment and Resources 34: 97-125. https://doi.org/10.1146/ annurev.environ.032108.105046

Teixeira PEG, Fernandes AR, Galvao JR, Pereira WVdS, Casanova SRA, Filho PPdCA. 2016. Cowpea yield on soils with residues of NPK and natural phosphate fertilizers in succession the area of degraded pasture. Rev. Ceres 63(4): 553-567. https://doi.org/10.1590/0034-737X2016630400 S17

Wahyunto, Shofiyati R. 2013. Wilayah Potensial Lahan Kering untuk Mendukung Pemenuhan Kebutuhan Pangan di Indonesia. Dalam Prospek Pertanian Lahan Kering Dalam Mendukung Ketahanan Pangan. IAARD Press. Jakarta (ID). 397 hal. 